\title{
INFLATION, PRODUCTIVITY, AND RELATIVE PRICES-A STATISTICAL STUDY
}

\author{
H. Glejser
}

$\mathrm{T}$ HIS paper investigates the influence of (1) inflation and (2) increases in labor productivity in industry on the magnitude of relative price changes in the long run.

The method followed is intercountry comparison. The magnitude of changes in the relative prices of consumer goods ${ }^{1}$ in the postwar period is computed for a set of countries and correlated with the yearly rate of increase in the consumption price level and in industrial productivity (i.e., output per man-hour) of the same country. The magnitude of relative price changes is defined as follows: The average yearly price index of each good or service is divided by the average yearly price index of total consumption. This gives the average annual ratio of change in the relative price of this good. Then the standard deviation of these ratios is computed, each ratio being weighted by the percentage of the good in total consumption. This standard deviation measures the magnitude of relative price changes.

In order to make definite conclusions possible, consumption should be broken down into as many goods - or rather categories of goods - as possible in order to avoid the blurred picture presented by compensating price moves within the categories. But on the other hand, the categories must be the same for the various countries, else comparisons would make little sense. The problem posed by scarce statistical data is solved in this way: for 15 countries, private consumption is split into only seven comparable categories of goods; for four countries, it is split into about 40 comparable categories; and for two countries, it is split into about 110 comparable categories.

\footnotetext{
${ }^{1}$ We chose prices of consumer goods because they constitute about two-thirds of national product; because comparable data are available for many countries; and because it is easier to attach a weight to each product than say, to a wholesale price index. Prices of investment goods are left out of the study as a change in the relative price of investment as a whole compared to consumption as a whole might be influenced by a modification in the distribution of income between capital and labour, a problem which we did not feel able to cope with for the moment.
}

Thus, as we press deeper into the detail of the products, we have to limit ourselves to a smaller number of countries.

\section{Fifteen Countries, Seven Categories of Products}

The seven categories are rent, heating and lighting, food, beverages and tobacco, consumer durables, clothing, and miscellaneous (mostly services). Table 1 presents the values taken by the three variables considered during the period 1953-1959. It must be pointed out that the figures on productivity increases are particularly shaky.

Table 1.-Average Annual Rate of Change of Relative Prices (yor Seven Categories of Products), of Total Consumption Price Level, and of Industrinl Productivity from 1953 to $1959^{*}$

\begin{tabular}{|c|c|c|c|c|c|c|}
\hline \multirow[b]{2}{*}{ Country } & \multicolumn{2}{|c|}{$\begin{array}{c}\text { Standard } \\
\text { deviation } \\
\text { of relative } \\
\text { prices } \\
\end{array}$} & \multicolumn{2}{|c|}{$\begin{array}{c}\text { Rate } \\
\text { of } \\
\text { inflation }\end{array}$} & \multicolumn{2}{|c|}{$\begin{array}{c}\begin{array}{c}\text { Rate of } \\
\text { productivity } \\
\text { increase } \\
(1953-1958)\end{array} \\
\end{array}$} \\
\hline & $\%$ & Rank & $\%$ & Rank & $\%$ & Rank \\
\hline France & 2.23 & 1 & 4.36 & 2 & 5.7 & 3 \\
\hline Greece ${ }^{b}$ & 1.89 & 2 & 5.43 & 1 & 4.2 & 5 \\
\hline Netherlands & 1.78 & 3 & 2.66 & 7 & 3.5 & 7.5 \\
\hline Italy & 1.64 & 4.5 & 1.91 & 10 & 6.2 & 1 \\
\hline Austria & 1.62 & 4.5 & 2.47 & 9 & 4.4 & 4 \\
\hline United Kingdom & 1.55 & 6.5 & 3.02 & 5 & 3.2 & 9.5 \\
\hline Sweden & 1.54 & 6.5 & 3.05 & 5 & 3.2 & 9.5 \\
\hline Norway & 1.43 & 8 & 3.31 & 3 & 2.8 & 11 \\
\hline Germany (F.R.) & 1.07 & 9 & 1.80 & 11 & 5.9 & 2 \\
\hline Canada & 1.02 & 10 & 1.50 & 12 & 3.5 & 7.5 \\
\hline United States & 0.93 & 12.5 & 1.41 & 13.5 & 0.6 & 15 \\
\hline Switzerland ${ }^{\text {b }}$ & 0.93 & 12.5 & 1.23 & 15 & 1.6 & 13 \\
\hline Denmark & 0.90 & 12.5 & 3.02 & 5 & 2.7 & 12 \\
\hline Belgium & 0.88 & 12.5 & 1.40 & 13.5 & 4.1 & 6 \\
\hline Ireland & 0.80 & 15 & 2.54 & 8 & 0.8 & 14 \\
\hline
\end{tabular}

: Sources and explanations appear in appendix 1
* For Greece and Switzeriand, no data are available for two of the seven categories: beverages and tobacco and consumer durables. Thus consumption was considered as composed only of the five remaining categories.

Computing a linear regression by the method of least squares, with the standard deviation of relative prices as dependent variable $y$ and the rates of inflation and of productivity increase as independent variables $x_{1}$ and $x_{2}$ respectively, we obtain the following equation:

$$
y=\underset{(0.060)}{0.223} x_{1}+\underset{(0.045)}{0.137} x_{2}+\underset{(0.066)}{0.288} \quad R=0 .
$$


All the coefficients differ significantly from zero at the one per cent level of significance, so a positive correlation seems to exist between the magnitude of relative price moves, on the one hand, and the rate of inflation and of productivity increase, on the other hand. Tentative explanations of this correlation will be given in section IV.

A few conclusions may be drawn. The (unweighted) arithmetic mean of $y$ for the 15 countries is 1.35 ; that of $x_{1}, 2.61$, and that of $x_{2}, 3.5$. Replacing the variables by their mean in equation (1), we get:

$$
1.35=0.58+0.48+0.29 .
$$

Thus, on the average, inflation accounted for nearly one-half of the magnitude of relative price moves, productivity increase accounted for more than one-third, and the passage of time (constant term) accounted for a little more than one-fifth. The latter reflects the effects of variables correlated with time such as modifications in the curves of demand for or supply of the different goods etc. Another conclusion of this analysis is that there is no significant correlation between inflation and rise in productivity. ${ }^{2}$ We find, indeed, the low value for $r_{w_{1} w_{2}}$ of 0.29 . except for France in the period 1959-1960, the standard deviation of relative prices is higher than in the preceding table. This is normal as (a) 40 products are distinguished instead of seven, and (b) as the periods considered here comprise the very severe Korean inflation.

One can see that the countries rank in the same order for the standard deviation of relative prices and for the inflation rate. This confirms the conclusion of the preceding section where inflation was found to be the most important explanatory variable of the magnitude of relative price changes.

A comparison between the evolution in France during the period 1950-1956 and 19501960 seems however to upset these findings. The magnitude of relative price changes was smaller in the latter period albeit the inflation rate was larger and the productivity increase about the same, but an important difference between the two inflationary periods is that the former knew no devaluation while the latter entailed two devaluations (mid-1957 and end1958). This provides us with a valuable hint as to one of the possible explanations of the link between inflation and moves in relative prices (see section IV).

Table 2. - Annual Rate of Change of Relative Prices (40 Categories of Products), of Total. Consumption Price Level, and oy Industrial Productivity in the Fifties *

\begin{tabular}{|c|c|c|c|c|c|c|c|}
\hline \multirow[b]{2}{*}{ Country } & \multirow[b]{2}{*}{ Period } & \multicolumn{2}{|c|}{$\begin{array}{l}\text { Standard deviation } \\
\text { of relative prices }\end{array}$} & \multicolumn{2}{|c|}{ Rate of inflation } & \multicolumn{2}{|c|}{$\begin{array}{c}\text { Rate of } p \\
\text { (productivity } \\
\text { increase) }\end{array}$} \\
\hline & & $\%$ & Rank & $\%$ & Rank & $\%$ & Rank \\
\hline 1. France & $1950-1956$ & 2.83 & 1 & 5.40 & 1 & $6.4(1953 / 56)$ & 1 \\
\hline France & $1950-1960$ & 2.21 & & 5.89 & & $6.3(1953 / 60)$ & \\
\hline 2. Sweden & $1948-1955$ & 2.10 & 2 & 4.47 & 2 & $2.7(1950 / 55)$ & 3.5 \\
\hline 3. United Kingdom & 1949-1959 & 1.95 & 3 & 3.82 & 3 & $2.8(1950 / 58)$ & 3.5 \\
\hline 4. Belgium & $1948-1960$ & 1.65 & 4 & 1.72 & 4 & $3.9(1948 / 58)$ & 2 \\
\hline
\end{tabular}

* Sources and explanations appear in appendix II.

\section{Four Countries, Forty Categories of Products}

The results obtained for four countries and 40 categories of products are presented in table 2. The figures are not strictly comparable with those of table 1 as periods and sources differ. However, one can notice that for all countries,

\footnotetext{
'E. H. Brown and M. H. Browne reached a similar conclusion. See their article "Income Distribution and Productivity Under Inflation 1947-1957," Economic Journal, No. 280 (Dec., 1960), in particular 741-745.
}

\section{Two Countries, 110 Categories of Products}

Table 3 presents the results for the two countries studied - France and Belgium.

A comparison with table 2 shows a rise of the same order of magnitude (16\% and $18 \%)$ for the standard deviation of relative prices in both countries as the number of categories considered increases from 40 to $110-2.56 \%$ against $2.21 \%$ for France and $1.95 \%$ against $1.65 \%$ for Belgium. 
Table 3.- Annual Rate of Change of Relative Prices (110 Categories of Products), of Total. Consumption Price Level, and of Industrial. Productivity in the Fiftes *

\begin{tabular}{lcccc}
\hline \hline Country & Period & $\begin{array}{c}\text { Standard } \\
\text { deviation } \\
\text { of relative } \\
\text { prices } \\
(\%)\end{array}$ & $\begin{array}{c}\text { Rate of } \\
\text { inflation } \\
(\%)\end{array}$ & $\begin{array}{c}\text { Rate of } \\
\text { productivity } \\
\text { increase } \\
(\%)\end{array}$ \\
\hline France & $1950-1960$ & 2.56 & 5.89 & $6.3(1953 / 1960)$ \\
Belgium & $1948-1960$ & 1.95 & 1.72 & $3.9(1948 / 1958)$ \\
\hline
\end{tabular}

- Sources are the same as for table 2 - see appendix II.

\section{Tentative Explanations of the Results}

The positive correlation between the magnitude of changes in relative prices and the increase in industrial productivity does not require many comments. As labour productivity cannot augment, or can augment only slowly in several branches, especially services (transport, distribution, entertainment, domestic services, etc.) the rise in their relative price is, ceteris paribus, an increasing function of productivity gains in the other branches (mainly industry). This is a well known phenomenon since Harrod's famous classification of goods into categories $A, B$, and $C$. $^{3}$

The positive correlation with inflation is somewhat more puzzling. Inflation is generally considered as a wave lifting the whole of prices to a higher level without altering significantly the respective position of each of them, at least in the long run. Such a view is contradicted by the statistical evidence on the evolution in the fifties. Explanations of the link between both variables can be sought along the following lines:

1) Demand inflation means pressure on limited resources but, however acute it may be, not necessarily in all branches. Overcapacity in some industries may not disappear and may coexist with shortages in others owing to stickiness of production factors. ${ }^{4}$ This could give rise to changes in relative prices, the magnitude of which would be an increasing function of the pressure of demand on the resources in short supply.

That such a situation is not purely imaginary is supported by a few examples.

${ }^{2}$ R. F. Harrod, International Economics, 3rd. ed. (Chicago: University of Chicago Press, 1933), chap. IV.

' Such a view is exposed by the group of independent experts appointed by the O.E.E.C. See The Problem of Rising Prices (Paris: O.E.E.C., 1961), 34 and 43-44.
Any explanation of the 1955-58 price experience (in the U.S.) must give special weight to the fact that the 1955-57 boom was concentrated in durable manufactured goods. Demand strained production capacity in the machinery and equipment industries ..... In this sector of the economy, prices and wages rose sharply. More than three-fourths [italics added] of the 1955-58 rise in the index of wholesale industrial prices was directly attributable to price increases in metals and metal products and machinery and motive products (including motor vehicles). Substantial employment cost increases were negotiated in the automobile settlement of 1955 and the steel settlement of 1956 . Both were three-year agreements, with the result that large wage commitments made in a boom environment became effective as the economy was slowing down. ${ }^{5}$

In Europe too, the main impact of the 19551957 boom seems to have been on investment goods and consumer durables. ${ }^{\circ}$

In 1962, a year of boom, the business tests undertaken in the Common Market countries showed important discrepancies in the rates of capacity utilization among industries. ${ }^{7}$ For Belgium, in November 1962, the median rate amounted to about 85 per cent, with a range extending from 65 per cent in shipbuilding and the leather industry to 95 per cent in the paper and board, the machine tool, and the textile machines industries. (Due allowances should, of course, be made for lack of comparability of the figures because of the conceptual difficulty of defining capacity in a branch.)

2) There might also be differences in the response of the various industries to demand inflation. The validity of a distinction between inflexible administered prices associated with oligopoly and flexible market prices associated with free competition has given rise to much dispute in the last 25 years. ${ }^{8}$ The group of independent experts of the O.E.E.C. deems the distinction relevant as far as short-period fluctuations in demand are concerned.

[This] should be fairly evident without very sophisticated analysis to anybody who is aware of the price behaviour of, for example, nearly all branded goods, or

"Council of Economic Advisers, Economic Report of the President (Washington: Jan, 1962), 171.

- The Problem of Rising Prices (O.E.E.C., 1961), 37.

'Commission de la Communauté Economique Européenne L'Enquête de conjoncture auprès des chefs d'entreprise de la Communauté (Bruxelles: novembre 1962), 34.

"For references on this subject, see W. J. Yordon, "Industrial Concentration and Price Flexibility in Inflation: Price Response Rates in Fourteen Industries, 1947-58," this sEvirw (Aug., 1961), 287-294. 
of the changes in delivery delays and order books of less homogeneous manufactured goods. Anybody who believes that prices of manufactured goods are adjusted frequently to clear the market should contemplate the long waiting lists that have existed for years for many makes of cheaper automobiles in several countries.... [However] the prices of manufactured goods in the United States seemed to be more sensitive to demand pressures than in Europe, at least ... during the years $1955-1957.9$

Differences in the response of concentrated and unconcentrated industries to demand pressures could thus explain relative price changes.

3) So much for demand inflation. But cost inflation can also act as a distorting factor. It is indeed likely to develop in branches where trade unions are strong or where oligopoly has replaced free competition among entrepreneurs. The "Economic Report of the President" of January 1962 gives examples of such facts for the United States.

The movement of wages during this period (post Korean years), reflected in fact the power exercised in labor markets by strong unions and the power possessed by large companies to pass on higher wage costs in higher prices. Although the high demand of the 195557 period was concentrated in the area of durable manufactures, wages also rose by substantial increments in some less prosperous but highly organized industries. ${ }^{10}$

A dissident view on this point is however expressed by the group of independent experts of the O.E.E.C. ${ }^{11}$

4) Another explanatory factor is government policy. One should keep in mind that some creeping postwar inflation still existed in

135. As far as the United States (1947-1958) are concerned W. J. Yordon indeed reached the conclusion that ". . . none of the findings offers much support for the view that the mechanics of price change in concentrated industries provide a dampering effect on the rate at which inflationary pressures are transmitted through the economy ..." op. cit, 292 .

${ }^{10}$ Council of Economic Advisers, op. cit., 175.

${ }^{11}$ The Problem of Rising Prices, (O.E.E.C., 1961), 468. many countries in the early fifties, subdued by price controls on some products, the most striking example being rents. At the outset, prices were thus not in equilibrium. As the controls were released, readjustments took place involving a rise in the absolute level of prices together with changes in relative prices. A few examples of such readjustments are the important rises in the relative price of rents in France, Greece, Italy, the Netherlands, Norway, and the United Kingdom and of food in Norway and the United Kingdom.

Conversely, in the countries experiencing a "new wave" of inflation, governments reintroduced controls on some prices, thus provoking a spill-over of inflation on uncontrolled prices. In France, for example, during the period 19561959 , several goods included in the official price index were subsidized in order to attenuate wage increases.

5) Finally, we shall point to a specific feature of the fifties: the fall in the prices of raw materials and foodstuffs. ( $A$ goods in Harrod's terminology.) As a consequence, the gap between these prices in dollars on the world market and the internal prices (i.e., prices of $B$ and $C$ goods) in a country has been an increasing function of the inflation rate in that country as long as the parity of its currency with the dollar was not modified. Some support for such an explanation is to be found in the fact that the magnitude of relative price changes in France was smaller from 1950 to 1960 than from 1950 to 1956 though inflation was more severe (see table 2), as devaluations took place in 1957 and 1958 which reduced the discrepancy between prices of $A$ goods and of $B$ and $C$ goods expressed in dollars.

A more thorough examination of the arguments here expressed, consisting, inter alia, in a close examination of the price evolution per product is required. We hope to undertake it some day.

\section{APPENDIX I}

The consumer price indices in the 15 countries used to compute columns 1 to 4 of table 1 are taken from The Problem of Rising Prices by the group of independent experts of the O.E.E.C. Paris 1961, Appendix 1 , tables 1 and 7 and these figures are generally those published in the O.E.E.C. General Statistical Bulletins, except for Belgium, Denmark, and Italy. For Belgium the indices are those of the national accounts; for Denmark, the official Consumer Price Index adjusted to eliminate direct taxes was used; for Italy, we have chosen the Consumer Price Index and not the Cost of Living Index shown in the O.E.E.C. Statistical Bulletin. 
The weights of the products are their percentages in total consumption in 1959.

Data on the evolution of labour productivity in industry were taken: from Europe's Needs and $R e$ sources by Dewhurst et. al. London 1961, Table 4-2, p. 115, for Austria, Denmark, Germany, Italy, the Netherlands, Norway, Sweden and the United Kingdom; from the O.E.E.C. General Statistical Bulletins (Index of production in manufacturing divided by the product of the index of employment in manufacturing by the index of average hours worked per week) for Canada, France, Greece, Ireland, Switzerland and the United States; for Belgium, we divided the index of value added in industry appearing in national accounts (Cahiers Economiques de Bruxelles no. 12, octobre 1961, p. 474) by the index of hours worked in industry (as estimated by R. E. Falleur in "La Quantité de Travail en Belgique," Cahiers Economiques de Bruxelles no 2, janvier 1959 , table 8 p. 269).

\section{APPENDIX II}

In tables 2 and 3 , price indices of consumer goods are national account data. Sources are: for France, Consommation published by the Centre de Recherche et de Documentation sur la Consommation du Ministère des Finances, nos. 3 and 4, juillet-décembre 1961; for Belgium, Cahiers Economiques de Bruxelles no. 9; for Sweden, Den privata konsumtionen i Sverige 193165 by R. Bentzel, K. Eklöf et al., Stockholm 1957,
Appendix 1, tables B and D; for the United Kingdom, Blue Book on National Income Expenditure, 1960.

The products are weighted by their percentages in total consumption in the middle of the period examined.

For productivity, sources are those described in Appendix I except for Sweden and the United Kingdom, for which figures were taken this time from the O.E.E.C. General Statistical Bulletins. 